\title{
The Implications of COVID-19 on Chinese Consumer Preferences for Lamb Meat
}

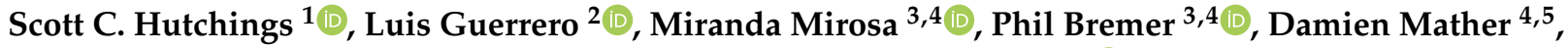 \\ Enrique Pavan ${ }^{1,6}$, Talia M. Hicks ${ }^{1}$, Li Day ${ }^{1}$ and Carolina E. Realini ${ }^{1, *} \mathbb{C}$
}

1 AgResearch Limited, Te Ohu Rangahau Kai, Massey University Campus, Grasslands, Tennent Drive, Palmerston North 4474, New Zealand; Scott.Hutchings@agresearch.co.nz (S.C.H.); Enrique.Pavan@agresearch.co.nz (E.P.); Talia.Hicks@agresearch.co.nz (T.M.H.); Li.Day@agresearch.co.nz (L.D.)

2 IRTA-Monells, Finca Camps i Armet, 17121 Monells, Spain; Lluis.Guerrero@irta.cat

3 Department of Food Science, University of Otago, P.O. Box 56, Dunedin 9054, New Zealand; miranda.mirosa@otago.ac.nz (M.M.); phil.bremer@otago.ac.nz (P.B.)

4 New Zealand Food Safety Science Research Centre, Hopkirk Research Institute, Tennent Drive, Massey University, Palmerston North 4442, New Zealand; damien.mather@otago.ac.nz 5 Department of Marketing, University of Otago, P.O. Box 56, Dunedin 9054, New Zealand

6 Instituto Nacional de Tecnología Agropecuaria, Balcarce 7620, Argentina

* Correspondence: carolina.realini@agresearch.co.nz

check for updates

Citation: Hutchings, S.C.; Guerrero, L.; Mirosa, M.; Bremer, P.; Mather, D.; Pavan, E.; Hicks, T.M.; Day, L.; Realini, C.E. The Implications of COVID-19 on Chinese Consumer Preferences for Lamb Meat. Foods 2021, 10, 1324. https://doi.org/ 10.3390 /foods 10061324

Academic Editor: María Del Mar Campo Arribas

Received: 15 May 2021

Accepted: 4 June 2021

Published: 8 June 2021

Publisher's Note: MDPI stays neutral with regard to jurisdictional claims in published maps and institutional affiliations.

Copyright: (c) 2021 by the authors. Licensee MDPI, Basel, Switzerland. This article is an open access article distributed under the terms and conditions of the Creative Commons Attribution (CC BY) license (https:// creativecommons.org/licenses/by/ $4.0 /)$.

\begin{abstract}
This study assessed if Chinese consumer attitudes towards a range of lamb attributes (such as origin, food safety, appearance, taste, price), and their opinions of New Zealand lamb (9- and 7-point Likert scales, respectively), had changed since the outbreak COVID-19. The same survey was carried out in Shanghai and Beijing pre (December 2018) and post COVID-19 (November 2020), $\sim 9$ months after China's initial outbreak, with 500 and 523 consumers, respectively. From December 2018 to November 2020, there was an increase in the proportion of Chinese consumers purchasing red meat online or from a butcher, and cooking their lamb well-done. In contrast, there were minimal differences in Chinese consumer ratings between December 2018 and November 2020 for different lamb attributes and opinions of New Zealand lamb. Cluster analysis revealed that many consumers (140 in December 2018/376 in November 2020) used only a small portion of the high end of the scale when rating lamb attributes, resulting in little differences between the attributes. This study suggests COVID-19 has enhanced some food safety related behaviors but had little effect on Chinese opinions and preferences for New Zealand lamb attributes. It also highlights that survey design should be carefully considered when collecting responses from Chinese consumers.
\end{abstract}

Keywords: COVID-19; lamb; meat; consumer; preference

\section{Introduction}

As a result of the global COVID-19 pandemic, food producers and processors are faced with the possibility of changing consumer attitudes towards their products in markets all around the world. As well as COVID-19 being shown to commonly affect sensory acuity while people are infected with the disease [1], and in some cases after recovery [2], the pandemic has also been reported to change the way consumers view, interact, purchase, prepare and eat food [3-5]. In particular, recent studies have shown an increase in online purchasing of food [6-9], an increase in consumer demand for healthy and nutritious food [7,10], and an increase in consumer demand for long shelf-life food [3], since the COVID-19 outbreak. Consequently, there is a need for improved understanding of these changing attitudes and behaviours to assist producers and processers to remain competitive in the COVID-19 marketplace.

One food sector where it is particularly important to understand changes in consumer attitudes is the meat sector where food quality and safety are of paramount importance to 
consumers [11]. It has already been suggested that the COVID-19 pandemic has changed public awareness of illness linked to animals and altered meat consumption patterns, at least in the short term [12]. As a case study, the attitude of Chinese consumers to New Zealand lamb was selected for investigation. New Zealand lamb meat has historically had a reputation with international consumers as a safe, high-quality product, produced from a 'clean and green' environment [13]. Furthermore, lamb (and other red meats) have a longer shelf life than many other meats, such as poultry and fish [14]. Lamb is one of New Zealand's most exported products, accounting for over NZD \$3 billion in revenue each year [15], with China currently New Zealand's largest importer of lamb meat [16]. China, the first country to suffer from the effects of COVID-19, and one of the world's largest economies and largest importers of food, is a major market for most nations who export red meat [17].

One approach by which changes in Chinese consumer perception of New Zealand lamb meat can be measured before and after COVID-19 is through an online, quantitative consumer survey. In December 2018, approximately one year prior to the outbreak of COVID-19, AgResearch Ltd. completed an online quantitative survey with 250 Chinese consumers in Shanghai and 250 Chinese consumers in Beijing, on the importance of various meat attributes at the point of purchase and on the opinions of New Zealand lamb. Hence, for a timely assessment of consumer attitudes since the outbreak of COVID-19, an opportunity arose to repeat the same survey online with a similar number of consumers in the same location (Shanghai and Beijing) in November 2020.

The objectives of this study were, therefore, to determine if Chinese consumer attitudes towards a range of lamb attributes (such as animal origin, food safety, appearance, taste, price, brand), as well as their opinions of New Zealand lamb, have changed since the outbreak COVID-19, and if so how. It was hypothesized that since the outbreak of COVID-19, Chinese consumers would place more importance on the health, food safety, and price related attributes of lamb. It was also hypothesized that Chinese consumer opinions of New Zealand lamb as a nutritious/healthy, safe, and high-quality product would change.

\section{Materials and Methods}

\subsection{Data Collection and Sample Characteristics}

The survey in December 2018 involved recruiting five hundred consumers $(n=250$ in Beijing and $n=250$ in Shanghai), while the survey in November 2020 involved recruiting five hundred and twenty-three consumers ( $n=265$ in Beijing and $n=258$ in Shanghai). Participants were recruited according to the following criteria: 18-75 years old, 50:50 male:female, and screening ensured that all recruited consumers ate lamb at least once per fortnight. A summary of the demographic characteristics of the four population groups is shown in Table 1.

Table 1. Demographic characteristics of consumers (\%).

\begin{tabular}{|c|c|c|c|c|c|}
\hline & & $\begin{array}{c}\text { Beijing } \\
\text { December } 2018\end{array}$ & $\begin{array}{c}\text { Shanghai } \\
\text { December } 2018\end{array}$ & $\begin{array}{c}\text { Beijing } \\
\text { November } 2020\end{array}$ & $\begin{array}{c}\text { Shanghai } \\
\text { November } 2020\end{array}$ \\
\hline \multirow{2}{*}{ Gender } & Male & 50.0 & 50.0 & 51.7 & 50.4 \\
\hline & Female & 50.0 & 50.0 & 48.3 & 49.6 \\
\hline \multirow{5}{*}{ Age } & $18-25$ & 13.2 & 12.8 & 12.8 & 12.8 \\
\hline & $26-35$ & 23.2 & 18.8 & 21.9 & 20.9 \\
\hline & $36-45$ & 13.6 & 18.4 & 15.5 & 16.3 \\
\hline & $46-60$ & 47.6 & 47.2 & 46.8 & 46.9 \\
\hline & $61+$ & 2.4 & 2.8 & 3.0 & 3.1 \\
\hline \multirow{7}{*}{ Education } & none & 0 & 0 & 0 & 0.4 \\
\hline & China elementary school & 0 & 0 & 0 & 0.0 \\
\hline & Chinese junior high graduate & 0.8 & 0.0 & 2.3 & 3.1 \\
\hline & Chinese high school & 2.8 & 5.2 & 13.6 & 12.0 \\
\hline & Trades certificate & 38.8 & 34.4 & 25.3 & 20.5 \\
\hline & Tertiary qualification & 57.6 & 60.4 & 58.9 & 64.0 \\
\hline & Labourer & 1.2 & 1.2 & 0.4 & 0.4 \\
\hline
\end{tabular}


Table 1. Cont.

\begin{tabular}{|c|c|c|c|c|c|}
\hline & & $\begin{array}{c}\text { Beijing } \\
\text { December } 2018\end{array}$ & $\begin{array}{c}\text { Shanghai } \\
\text { December } 2018\end{array}$ & $\begin{array}{c}\text { Beijing } \\
\text { November } 2020\end{array}$ & $\begin{array}{c}\text { Shanghai } \\
\text { November } 2020\end{array}$ \\
\hline \multirow{7}{*}{ Income } & Less than 50,000 CNY & 1.2 & 1.6 & 0.4 & 0.8 \\
\hline & 50,001 to $100,000 \mathrm{CNY}$ & 5.2 & 3.6 & 2.3 & 0.8 \\
\hline & 100,001 to $150,000 \mathrm{CNY}$ & 17.2 & 13.2 & 10.6 & 7.0 \\
\hline & 150,001 to $200,000 \mathrm{CNY}$ & 23.2 & 22.4 & 32.5 & 27.1 \\
\hline & 200,001 to $300,000 \mathrm{CNY}$ & 32.0 & 39.2 & 24.2 & 33.7 \\
\hline & 300,001 to $500,000 \mathrm{CNY}$ & 14.8 & 15.2 & 20.0 & 22.5 \\
\hline & More than $500,000 \mathrm{CNY}$ & 6.4 & 4.8 & 10.2 & 8.1 \\
\hline
\end{tabular}

The online survey in December 2018 was undertaken by the market research company COFCO Corporation (Beijing, China), while the online survey in November 2020 was undertaken by the market research company Dynata (Auckland, New Zealand). Both COFCO and Dynata used standard quality control techniques to ensure all responses were given by unique individuals without duplication or fraudulent responses. This survey was approved by the University of Otago Human Ethics Committee (Category B), application number D20/355.

\subsection{Questionnaire}

The questionnaire asked participants about a variety of demographic details, dietary and purchasing habits, lamb attributes of interest at the point of purchase and the type of lamb products they typically purchase. To gain insight into consumer considerations at the point of purchase, consumers rated the level of importance of varying aspects of lamb meat purchase on a scale of one ("not important") to nine ("very important"). These aspects included animal factors and other production factors, pricing factors, intrinsic cues of the meat, convenience factors and personal knowledge of commercial cuts. To gain their opinion on New Zealand lamb meat, each consumer also rated their degree of agreement on several descriptions of the lamb meat on a scale of one ("strongly disagree") to seven ("strongly agree"). New Zealand lamb meat was described in several ways, including, but not limited to, as nutritious, safe, good value for money, produced sustainably and convenient. The 9-point scale used to measure importance, and the 7-point scale used to measure opinions, are widely used forms of Likert scales for measuring consumer opinions of food $[18,19]$.

The questionnaire was designed in English by the researchers before a native speaker of Mandarin translated the questionnaire into Mandarin. The Mandarin version included some small adaptations from the original English version to accommodate Chinese consumers. A complete copy of the English version of the survey can be found in Appendix A of this publication.

\subsection{Data Analysis}

IBM SPSS (V27) was used to analyze data. For data on demographic factors, diet and consumption patterns, a Chi-squared test was performed to firstly determine the effect of year (December 2018 vs. November 2020), and then the effect of city (Shanghai vs. Beijing). A two-way ANOVA was applied to the scale data on consumers' rating of importance of lamb meat attributes at the point of purchase and their opinion on New Zealand lamb meat to determine the effect of year (December 2018 vs. November 2020), the effect of city (Shanghai vs. Beijing), and the effect of any year $\times$ city interaction.

An agglomerative hierarchical cluster analysis was performed on the square Euclidean distance matrix, with the Ward method, to identify three clusters of consumers based on their normalized scores for the level of importance of lamb attributes at the point of purchase using XLSTAT 2017 (Addinsoft 2012) software. 


\section{Results}

\subsection{Diet and Consumption Patterns of Consumers}

Diet and consumption patterns were significantly different between the December 2018 and November 2020 consumers for all diets and meat types that were questioned $(p<0.05)$. A significant city effect was only found for dietary restrictions and for beef consumption $(p<0.05)$, showing higher proportions of consumers following low calorie diets in Beijing than Shanghai, and greater beef consumption in Beijing than Shanghai. Consumers in November 2020 were less likely to follow any particular diet. In general terms, November 2020 consumers ate beef and lamb slightly more often and pork, poultry and fish slightly less often than December 2018 consumers (Table 2).

Table 2. Dietary restrictions and consumption frequency of animal protein sources (\%) ( $p$ value determined using a Chi-squared test for both year and city).

\begin{tabular}{|c|c|c|c|c|c|c|c|}
\hline & & $\begin{array}{c}\text { Beijing } \\
\text { December } \\
2018\end{array}$ & $\begin{array}{c}\text { Shanghai } \\
\text { December } \\
2018\end{array}$ & $\begin{array}{c}\text { Beijing } \\
\text { November } \\
2020\end{array}$ & $\begin{array}{l}\text { Shanghai } \\
\text { November } \\
2020\end{array}$ & $\begin{array}{c}p\left(\mathrm{Chi}^{2}\right) \\
\text { (Year) }\end{array}$ & $\begin{array}{c}p\left(\mathrm{Chi}^{2}\right) \\
\text { (City) }\end{array}$ \\
\hline \multirow{4}{*}{$\begin{array}{l}\text { Dietary } \\
\text { restrictions }\end{array}$} & Low salt & 72.8 & 73.6 & 63.8 & 60.9 & $<0.001$ & 0.725 \\
\hline & Low sugar & 71.2 & 72.8 & 65.7 & 59.3 & 0.001 & 0.413 \\
\hline & Low calories & 63.2 & 61.2 & 52.8 & 40.7 & $<0.001$ & 0.023 \\
\hline & Do not follow a diet & 10.8 & 7.6 & 30.2 & 31.0 & $<0.001$ & 0.571 \\
\hline \multirow{5}{*}{ Lamb } & Daily & 5.2 & 2.4 & 2.6 & 4.3 & \multirow{5}{*}{$<0.001$} & \multirow{5}{*}{0.110} \\
\hline & 4-5 times a week & 13.2 & 8.8 & 24.2 & 20.5 & & \\
\hline & 2-3 times a week & 25.2 & 23.2 & 23.4 & 17.8 & & \\
\hline & Weekly & 35.6 & 40.4 & 32.1 & 37.6 & & \\
\hline & Fortnightly & 20.8 & 25.2 & 17.7 & 19.8 & & \\
\hline \multirow{5}{*}{ Beef } & Daily & 3.2 & 2.0 & 10.6 & 4.7 & \multirow{5}{*}{$<0.001$} & \multirow{5}{*}{$<0.001$} \\
\hline & 4-5 times a week & 12.4 & 8.8 & 15.1 & 12.4 & & \\
\hline & 2-3 times a week & 35.2 & 42.8 & 34.3 & 32.2 & & \\
\hline & Weekly & 32.4 & 38.0 & 24.9 & 29.8 & & \\
\hline & Fortnightly or less & 16.8 & 8.4 & 15.1 & 21.0 & & \\
\hline \multirow{5}{*}{ Pork } & Daily & 14.8 & 12.4 & 11.7 & 11.2 & \multirow{5}{*}{$<0.001$} & \multirow{5}{*}{0.579} \\
\hline & 4-5 times a week & 26.0 & 26.4 & 25.3 & 19.0 & & \\
\hline & 2-3 times a week & 39.6 & 40.0 & 31.3 & 34.1 & & \\
\hline & Weekly & 15.2 & 11.6 & 24.2 & 29.8 & & \\
\hline & Fortnightly or less & 4.4 & 9.6 & 7.6 & 5.8 & & \\
\hline \multirow{5}{*}{ Poultry } & Daily & 8.0 & 4.4 & 6.0 & 2.7 & \multirow{5}{*}{$<0.001$} & \multirow{5}{*}{0.145} \\
\hline & 4-5 times a week & 13.2 & 12.0 & 14.7 & 11.6 & & \\
\hline & 2-3 times a week & 37.2 & 40.8 & 39.2 & 35.7 & & \\
\hline & Weekly & 32.4 & 30.4 & 29.1 & 41.1 & & \\
\hline & Fortnightly or less & 9.2 & 12.4 & 10.9 & 8.9 & & \\
\hline \multirow{5}{*}{ Fish } & Daily & 6.4 & 9.6 & 4.2 & 3.1 & \multirow{5}{*}{$<0.001$} & \multirow{5}{*}{0.774} \\
\hline & 4-5 times a week & 17.2 & 22.4 & 24.9 & 19.8 & & \\
\hline & 2-3 times a week & 38.0 & 40.4 & 33.6 & 27.9 & & \\
\hline & Weekly & 32.4 & 18.0 & 27.9 & 38.0 & & \\
\hline & Fortnightly or less & 6.0 & 9.6 & 9.5 & 11.3 & & \\
\hline
\end{tabular}

3.2. Preferred Level of Cooking, Meat Qualities of Interest, Purchase Location and Types of Lamb Products Typically Purchased

Many of the preferences measured in terms of cooking, location of purchase, and types of lamb products typically purchased differed significantly between December 2018 and November 2020 consumers $(p<0.05)$ (Table 3$)$. No city effect was found for any of the preferences measured $(p>0.05)$. 
Table 3. Preferred level of cooking, meat qualities of interest to consumers at the point of purchase and purchase and purchase frequency of different lamb products (\%) ( $p$ value determined using a Fishers exact test (Chi-squared) for both year and city).

\begin{tabular}{|c|c|c|c|c|c|c|c|}
\hline & & $\begin{array}{c}\text { Beijing } \\
\text { December } \\
2018 \\
\end{array}$ & $\begin{array}{c}\text { Shanghai } \\
\text { December } \\
2018 \\
\end{array}$ & $\begin{array}{c}\text { Beijing } \\
\text { November } \\
2020 \\
\end{array}$ & $\begin{array}{c}\text { Shanghai } \\
\text { November } \\
2020 \\
\end{array}$ & $\begin{array}{l}p\left(\mathrm{Chi}^{2}\right) \\
\text { (Year) }\end{array}$ & $\begin{array}{l}p\left(\mathrm{Chi}^{2}\right) \\
\text { (City) }\end{array}$ \\
\hline \multirow{5}{*}{$\begin{array}{l}\text { Preferred level of } \\
\text { cooking with lamb }\end{array}$} & Rare & 2.0 & 0.8 & 0.8 & 2.4 & \multirow{5}{*}{$<0.001$} & \multirow{5}{*}{0.133} \\
\hline & Medium/Rare & 6.0 & 7.6 & 3.8 & 2.7 & & \\
\hline & Medium & 8.0 & 12.4 & 7.2 & 3.9 & & \\
\hline & Medium/Well Done & 53.2 & 58.8 & 35.1 & 39.1 & & \\
\hline & Well Done & 30.8 & 20.4 & 53.2 & 51.9 & & \\
\hline \multirow{4}{*}{$\begin{array}{l}\text { Where do you purchase } \\
\text { red meat? }\end{array}$} & Supermarket & 92.4 & 91.6 & 84.5 & 90.7 & 0.023 & 0.150 \\
\hline & Butcher shop & 66.4 & 66.8 & 80.0 & 75.6 & $<0.001$ & 0.485 \\
\hline & Market & 32.0 & 33.6 & 39.2 & 33.3 & 0.238 & 0.470 \\
\hline & On-line & 8.0 & 12.4 & 26.4 & 31.8 & $<0.001$ & 0.060 \\
\hline \multirow{5}{*}{$\begin{array}{l}\text { What qualities do you } \\
\text { look for when } \\
\text { purchasing red meat? }\end{array}$} & Marbling & 52.4 & 50.4 & 52.5 & 55.0 & 0.491 & 0.950 \\
\hline & Leanness & 87.6 & 85.2 & 85.7 & 86.0 & 0.857 & 0.718 \\
\hline & Meat colour & 84.4 & 78.4 & 76.6 & 85.3 & 0.447 & 0.540 \\
\hline & Portion size & 42.0 & 43.2 & 37.0 & 38.4 & 0.111 & 0.702 \\
\hline & Price & 52.0 & 58.0 & 24.9 & 26.0 & $<0.001$ & 0.539 \\
\hline \multirow{9}{*}{$\begin{array}{l}\text { What lamb products do } \\
\text { you typically purchase? }\end{array}$} & Leg roast & 68.4 & 64.0 & 56.6 & 60.5 & 0.012 & 0.967 \\
\hline & Lamb chops & 56.8 & 59.2 & 40.8 & 46.9 & $<0.001$ & 0.169 \\
\hline & Lamb mince & 20.4 & 15.6 & 28.7 & 24.4 & $<0.001$ & 0.085 \\
\hline & Lamb rump & 32.0 & 29.6 & 38.5 & 41.1 & 0.003 & 0.975 \\
\hline & Lamb steaks & 61.6 & 56.8 & 56.2 & 70.2 & 0.223 & 0.124 \\
\hline & Lamb rack & 27.6 & 20.0 & 49.1 & 47.3 & $<0.001$ & 0.119 \\
\hline & Lamb sausages & 17.2 & 18.8 & 25.3 & 17.4 & 0.182 & 0.209 \\
\hline & Lamb shanks & 51.2 & 57.6 & 44.2 & 45.3 & 0.002 & 0.235 \\
\hline & Shoulder roast & 22.0 & 20.0 & 16.2 & 20.9 & 0.346 & 0.583 \\
\hline
\end{tabular}

A greater proportion of the November 2020 consumers preferred their lamb well done compared to the December 2018 consumers. A much greater proportion of the November 2020 consumers purchased red meat online as well as at butcher shops compared to December 2018 consumers. Compared to December 2018 consumers, November 2020 consumers typically purchased less leg roast, chops, and shanks, and more lamb mince, rump and rack. All meat qualities of interest for December 2018 consumers were similar to November 2020 consumers (marbling, leanness, colour and portion size), with the exception of price which was looked for more by the December 2018 consumers (Table 3).

3.3. Importance of Lamb Attributes at the Point of Purchase (e.g., Origin, Food Safety, Appearance, Taste, Price)

There was no significant interaction $(p>0.05)$ between year and city for consumers' rating of the relative importance of lamb attributes at the point of purchase. The importance of most lamb attributes was significantly lower $(p<0.05)$ with the November 2020 consumers compared to December 2018 consumers (both for Shanghai and Beijing) (Table 4). However, the size of these effects was not large- the difference between year groups on average was only around 0.5 on the 9-point importance scale. The importance of lamb attributes did not differ significantly between the two cities studied ( $p>0.05)$. 
Table 4. The relative importance of lamb attributes at the point of purchase (mean \pm SD) $(1=$ not important, $9=$ very important). ( $p$ value determined using a two-way ANOVA with year and city as the main effects).

\begin{tabular}{|c|c|c|c|c|c|c|c|}
\hline & $\begin{array}{c}\text { Beijing } \\
\text { December } \\
2018\end{array}$ & $\begin{array}{c}\text { Shanghai } \\
\text { December } \\
2018\end{array}$ & $\begin{array}{c}\text { Beijing } \\
\text { November } \\
2020\end{array}$ & $\begin{array}{c}\text { Shanghai } \\
\text { November } \\
2020\end{array}$ & $\begin{array}{l}p \text { (ANOVA) } \\
\quad \text { (Year) }\end{array}$ & $\begin{array}{c}p \\
\text { (ANOVA)(City) }\end{array}$ & $\begin{array}{c}p(\text { ANOVA }) \\
(\text { City } \times \text { Year })\end{array}$ \\
\hline Animal origin & $7.12 \pm 1.70$ & $7.22 \pm 1.47$ & $6.80 \pm 1.66$ & $6.62 \pm 1.64$ & $<0.001$ & 0.694 & 0.168 \\
\hline Animal welfare & $7.52 \pm 1.58$ & $7.56 \pm 1.35$ & $6.44 \pm 1.80$ & $6.56 \pm 1.69$ & $<0.001$ & 0.439 & 0.705 \\
\hline Animal feeding & $7.23 \pm 1.63$ & $7.39 \pm 1.49$ & $6.88 \pm 1.52$ & $6.87 \pm 1.48$ & $<0.001$ & 0.414 & 0.394 \\
\hline Animal age & $6.84 \pm 1.85$ & $6.94 \pm 1.62$ & $6.75 \pm 1.65$ & $6.48 \pm 1.64$ & 0.010 & 0.465 & 0.080 \\
\hline Animal sex & $5.70 \pm 2.28$ & $5.84 \pm 2.21$ & $6.34 \pm 1.96$ & $6.29 \pm 1.78$ & $<0.001$ & 0.736 & 0.474 \\
\hline $\begin{array}{c}\text { Presence of hormones and other } \\
\text { residues }\end{array}$ & $7.89 \pm 1.47$ & $7.98 \pm 1.29$ & $7.08 \pm 1.71$ & $7.09 \pm 1.55$ & $<0.001$ & 0.635 & 0.652 \\
\hline $\begin{array}{l}\text { Traceability (to know history of } \\
\text { meat you purchase) }\end{array}$ & $7.16 \pm 1.74$ & $7.33 \pm 1.54$ & $6.99 \pm 1.63$ & $6.76 \pm 1.67$ & $<0.001$ & 0.782 & 0.052 \\
\hline Lamb price & $6.85 \pm 1.72$ & $6.93 \pm 1.70$ & $6.73 \pm 1.67$ & $6.70 \pm 1.59$ & 0.094 & 0.813 & 0.597 \\
\hline Price of other meats & $6.59 \pm 1.83$ & $6.48 \pm 1.91$ & $6.56 \pm 1.77$ & $6.44 \pm 1.70$ & 0.737 & 0.319 & 0.969 \\
\hline Fat content of meat & $7.22 \pm 1.52$ & $7.35 \pm 1.45$ & $7.02 \pm 1.48$ & $6.83 \pm 1.62$ & $<0.001$ & 0.747 & 0.095 \\
\hline $\begin{array}{c}\text { General meat appearance (shiny, } \\
\text { dry...etc.) }\end{array}$ & $7.65 \pm 1.36$ & $7.75 \pm 1.32$ & $6.99 \pm 1.57$ & $7.09 \pm 1.58$ & $<0.001$ & 0.274 & 0.998 \\
\hline Meat colour & $7.60 \pm 1.55$ & $7.72 \pm 1.29$ & $7.06 \pm 1.54$ & $7.02 \pm 1.63$ & $<0.001$ & 0.646 & 0.417 \\
\hline Meat flavour & $7.57 \pm 1.45$ & $7.72 \pm 1.21$ & $7.06 \pm 1.47$ & $7.00 \pm 1.53$ & $<0.001$ & 0.591 & 0.241 \\
\hline Meat texture (tenderness) & $7.78 \pm 1.47$ & $7.91 \pm 1.15$ & $7.19 \pm 1.53$ & $7.09 \pm 1.62$ & $<0.001$ & 0.875 & 0.197 \\
\hline $\begin{array}{l}\text { Risk of catching a disease } \\
\text { consuming lamb (food safety) }\end{array}$ & $8.19 \pm 1.37$ & $8.17 \pm 1.28$ & $7.28 \pm 1.53$ & $7.31 \pm 1.49$ & $<0.001$ & 0.952 & 0.776 \\
\hline Place of purchase & $7.07 \pm 1.56$ & $7.01 \pm 1.74$ & $6.85 \pm 1.63$ & $6.86 \pm 1.49$ & 0.063 & 0.809 & 0.752 \\
\hline Trust in butcher & $6.61 \pm 1.69$ & $6.66 \pm 1.79$ & $6.86 \pm 1.62$ & $6.90 \pm 1.65$ & 0.022 & 0.668 & 0.950 \\
\hline $\begin{array}{c}\text { Time of the day in which you can } \\
\text { purchase lamb }\end{array}$ & $6.86 \pm 1.94$ & $7.03 \pm 1.82$ & $6.59 \pm 1.71$ & $6.58 \pm 1.70$ & 0.001 & 0.485 & 0.445 \\
\hline Brand or quality label & $7.72 \pm 1.37$ & $7.72 \pm 1.43$ & $6.94 \pm 1.65$ & $7.08 \pm 1.50$ & $<0.001$ & 0.474 & 0.423 \\
\hline Label information & $7.42 \pm 1.44$ & $7.56 \pm 1.47$ & $6.96 \pm 1.62$ & $6.98 \pm 1.53$ & $<0.001$ & 0.392 & 0.482 \\
\hline $\begin{array}{l}\text { Presentation (pieces, slices, trays, } \\
\text { etc.) }\end{array}$ & $7.13 \pm 1.58$ & $7.25 \pm 1.43$ & $6.67 \pm 1.70$ & $6.67 \pm 1.56$ & $<0.001$ & 0.533 & 0.551 \\
\hline Easy to prepare/cook & $7.34 \pm 1.43$ & $7.39 \pm 1.33$ & $6.97 \pm 1.60$ & $6.97 \pm 1.47$ & $<0.001$ & 0.814 & 0.806 \\
\hline Dish to be prepared with it & $6.98 \pm 1.72$ & $7.10 \pm 1.51$ & $6.75 \pm 1.56$ & $6.71 \pm 1.56$ & 0.002 & 0.722 & 0.394 \\
\hline $\begin{array}{l}\text { My knowledge of different } \\
\text { commercial cuts }\end{array}$ & $7.47 \pm 1.46$ & $7.40 \pm 1.52$ & $6.88 \pm 1.55$ & $6.84 \pm 1.41$ & $<0.001$ & 0.581 & 0.823 \\
\hline Value for money & $7.28 \pm 1.57$ & $7.40 \pm 1.55$ & $6.99 \pm 1.61$ & $6.72 \pm 1.65$ & $<0.001$ & 0.448 & 0.050 \\
\hline
\end{tabular}

Specifically, the November 2020 consumers showed significantly lower importance ratings $(p<0.05)$ than December 2018 consumers for the following attributes: animal origin, animal welfare, animal feeding, animal age, presence of hormones and other residues, traceability, appearance, colour, flavour, texture, food safety, time of day to purchase, brand / quality label, labelling presentation, ease of preparation, dish to be prepared with, knowledge of different commercial cuts, and value for money. November 2020 consumers showed significantly higher importance ratings $(p<0.05)$ for the sex of the animal, and the trust in the butcher. There was no significant difference between December 2018 and November 2020 consumers in importance ratings for lamb price, price of other meats, and place of purchase.

\subsection{Opinion on New Zealand Lamb}

Marginal year $\times$ city interactions were found for consumers' opinion regarding lamb being healthy, well known, and convenient. Opinions towards New Zealand lamb were also significantly different between December 2018 and November 2020 consumers for a number of attributes, however, as observed with importance ratings for attributes of lamb, the size of any significant effects for year were relatively small-usually less than 0.5 on the 7 point Likert scale. Only two attributes showed marginally significant effects between cities (natural and no additives) (Table 5). 
Table 5. Opinion of New Zealand lamb ( 1 = strongly disagree, $7=$ strongly agree) (mean \pm SD) ( $p$ value determined using a two-way ANOVA with year and city as the main effects).

\begin{tabular}{|c|c|c|c|c|c|c|c|}
\hline & $\begin{array}{c}\text { Beijing } \\
\text { December } \\
2018\end{array}$ & $\begin{array}{c}\text { Shanghai } \\
\text { December } \\
2018\end{array}$ & $\begin{array}{c}\text { Beijing } \\
\text { November } \\
2020\end{array}$ & $\begin{array}{l}\text { Shanghai } \\
\text { November } \\
2020\end{array}$ & $p \underset{\text { (Year) }}{p(\text { ANOVA) }}$ & $\begin{array}{c}p \\
\text { (ANOVA)(City) }\end{array}$ & $\begin{array}{c}p \text { (ANOVA) } \\
(\text { City } \times \text { Year })\end{array}$ \\
\hline Is nutritious & $6.01 \pm 0.99$ & $6.13 \pm 0.96$ & $5.54 \pm 1.03$ & $5.58 \pm 1.03$ & $<0.001$ & 0.208 & 0.474 \\
\hline Is healthy & $5.92 \pm 1.09$ & $6.12 \pm 0.95$ & $5.68 \pm 1.05$ & $5.59 \pm 1.00$ & $<0.001$ & 0.391 & 0.024 \\
\hline Is well known & $5.52 \pm 1.34$ & $5.72 \pm 1.25$ & $5.59 \pm 1.01$ & $5.48 \pm 1.07$ & 0.214 & 0.549 & 0.034 \\
\hline Is unique & $5.20 \pm 1.40$ & $5.43 \pm 1.30$ & $5.32 \pm 1.22$ & $5.38 \pm 1.06$ & 0.643 & 0.066 & 0.303 \\
\hline Is safe & $5.89 \pm 1.10$ & $6.03 \pm 0.99$ & $5.57 \pm 1.04$ & $5.55 \pm 1.06$ & $<0.001$ & 0.313 & 0.235 \\
\hline Is good value for money & $5.59 \pm 1.24$ & $5.78 \pm 1.02$ & $5.51 \pm 1.13$ & $5.51 \pm 1.06$ & 0.015 & 0.182 & 0.175 \\
\hline Is boring & $2.95 \pm 1.83$ & $3.11 \pm 1.91$ & $3.80 \pm 1.95$ & $3.59 \pm 2.07$ & $<0.001$ & 0.834 & 0.136 \\
\hline Is a traditional product & $5.22 \pm 1.25$ & $5.38 \pm 1.18$ & $5.18 \pm 1.32$ & $5.08 \pm 1.36$ & 0.036 & 0.707 & 0.105 \\
\hline Is natural & $5.72 \pm 1.23$ & $5.98 \pm 1.08$ & $5.58 \pm 1.00$ & $5.60 \pm 1.04$ & $<0.001$ & 0.047 & 0.070 \\
\hline Is hard to digest & $3.40 \pm 1.81$ & $3.43 \pm 1.94$ & $4.25 \pm 1.93$ & $3.88 \pm 1.99$ & $<0.001$ & 0.156 & 0.092 \\
\hline Is produced sustainably & $5.66 \pm 1.11$ & $5.76 \pm 1.12$ & $5.48 \pm 1.04$ & $5.56 \pm 1.04$ & 0.005 & 0.184 & 0.830 \\
\hline Is convenient & $5.33 \pm 1.22$ & $5.54 \pm 1.15$ & $5.49 \pm 1.06$ & $5.40 \pm 1.08$ & 0.857 & 0.408 & 0.034 \\
\hline Is readily available & $5.08 \pm 1.31$ & $5.25 \pm 1.14$ & $5.36 \pm 1.07$ & $5.37 \pm 1.20$ & 0.007 & 0.210 & 0.285 \\
\hline Is high quality & $6.02 \pm 1.01$ & $6.07 \pm 1.01$ & $5.65 \pm 1.09$ & $5.59 \pm 1.05$ & $<0.001$ & 0.952 & 0.391 \\
\hline Contains no additives & $5.58 \pm 1.16$ & $5.82 \pm 1.06$ & $5.53 \pm 1.07$ & $5.56 \pm 0.99$ & 0.022 & 0.044 & 0.131 \\
\hline Makes people feel good & $5.92 \pm 1.17$ & $6.00 \pm 0.96$ & $5.53 \pm 1.05$ & $5.47 \pm 1.11$ & $<0.001$ & 0.854 & 0.288 \\
\hline Tastes good & $6.01 \pm 0.93$ & $6.05 \pm 1.17$ & $5.57 \pm 1.07$ & $5.67 \pm 1.01$ & $<0.001$ & 0.269 & 0.664 \\
\hline
\end{tabular}

Specifically, November 2020 consumers' opinion of New Zealand lamb was lower than December 2018 consumers for the following attributes: nutritious, healthy, safe, value for money, traditional product, natural, produced sustainably, high quality, contains no additives, makes people feel good, tastes good $(p<0.05)$. November 2020 consumers $^{\prime}$ opinion of New Zealand lamb was higher than December 2018 consumers for hard to digest, boring, and readily available $(p<0.05)$. There was no difference between November 2020 and December 2018 consumers for well known, unique, and convenient $(p>0.05)$ (Table 5).

\subsection{Cluster Analysis}

Cluster analysis of the December 2018 consumers (Figure 1) revealed three clusters: Cluster 1 (159 consumers), Cluster 2 (156 consumers), and Cluster 3 (185 consumers). In two of these clusters (Clusters 1 and 2) consumers assigned different importance ratings for the lamb attributes, while in Cluster 3 they gave virtually the same importance ratings for all attributes. December 2018 consumers in Clusters 1 and 2 assigned different importance ratings to attributes such as animal sex, hormones/residues, lamb price, price of other meats, meat appearance, colour, flavour, texture, food safety, trust in butcher, brand/quality label, labelling, knowledge of commercial cuts, value for money.

Cluster analysis of the November 2020 consumers (Figure 1) also revealed three clusters: Cluster 1 (224 consumers), Cluster 2 (152 consumers), and Cluster 3 (147 consumers). Here, consumers in one cluster (Cluster 2) assigned different importance ratings to the lamb attributes, while in the two other clusters (Clusters 1 and 3) they gave virtually the same importance ratings for all attributes. In November 2020, consumers in Cluster 2 assigned different importance ratings to lamb attributes such as animal sex, hormones/residues, lamb price, price of other meats, meat appearance, colour, flavour, texture, food safety, time of day to purchase, brand quality, labelling, and ease of preparation. 

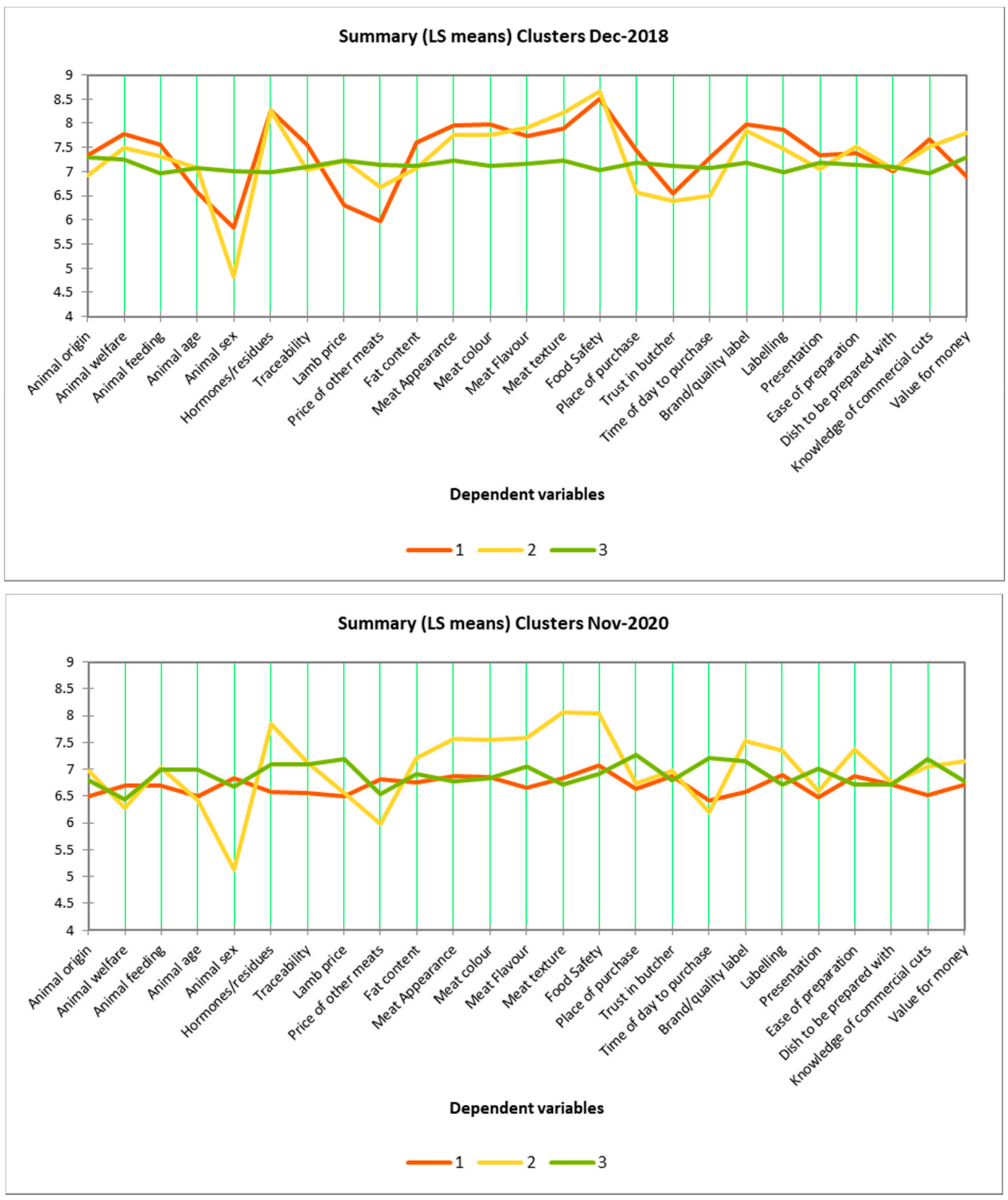

Figure 1. Cluster analysis of the importance ratings of lamb attributes at the point of purchase.

\section{Discussion}

4.1. The Effect of COVID-19 on Chinese Consumers' Purchase Methods and Preferred Level of Cooking

This study has found that there was an increase in the proportion of consumers buying their red meat either online or from butcher shops (consumers that purchased meat online increased from $10.2 \%$ across the two cities in December 2018, to $29.1 \%$ in November 2020 , and consumers that purchased meat from a butcher increased from $67 \%$ across the 
two cities in December 2018, to 78\% in November 2020 (Table 3)). The increase in online purchasing reflects the global trend in increased online purchasing since COVID-19 [6,7], a trend that has also been shown in many Asian markets such as China [8] and Taiwan [9]. The increase in purchasing from butcher shops is also indicative of consumers trying to avoid going to supermarkets where there are large numbers of people, instead preferring a local butcher (interestingly, results also showed an increase in their trust of the butcher from December 2018 to November 2020 (Table 4)).

While Chinese consumers typically cook their meat in a style that is thorough and hence safe for consumption [20], this study has shown that from December 2018 to November 2020 the proportion of consumers wanting their meat well done increased and those wanting medium or medium/rare decreased (Table 3). This effect is likely a result of an implicit increase in consumer desire to prepare safe food for consumption following COVID-19. An online survey of 999 US consumers reported that the importance of food safety attributes of beef increased significantly following COVID-19 [21]. In terms of China, an online survey of 1008 consumers reported that COVID-19 increased their food safety concerns towards game meat [22]. In the current study, there was an increase in consumption of beef and lamb from December 2018 to November 2020, but no increase in the consumption of pork, poultry or fish (Table 2). The superior shelf life of red meat compared to poultry and fish [14], and the recent associations of pork with virus outbreaks [23,24] and unfounded fears of imported Salmon spreading COVID-19 [25], may have all contributed to beef and lamb becoming a more preferred option for home cooking by Chinese consumers in November 2020. Interestingly, fewer consumers were concerned with the price of red meat in November 2020, which may be linked to an implicit increase that Chinese consumers were placing on food safety over cost.

\subsection{The Effect of COVID-19 on Chinese Consumer Responses towards the Importance of Lamb} Attributes and Their Opinions of New Zealand Lamb

In general, consumer responses towards the importance of lamb attributes and opinions towards New Zealand lamb were largely unchanged from December 2018 to November 2020. Results, therefore, suggest that the COVID-19 pandemic has had only a very minor effect on Chinese consumer preferences towards lamb. For both the relative importance of lamb attributes, and the consumer opinions of New Zealand lamb, the slight reduction in ratings which were observed may have occurred as a result of other COVID19 concerns (economic, health, family concerns) having greater priority for consumers. However, slight differences in the demographic characteristics or use of the scale between groups may be enough to explain these small effects.

Other literature that has recently been published in consumer science has shown an impact of COVID-19 on consumer attitudes towards food products in some cases. For example, consumers in Qatar have reported as having an increased desire towards healthier food products and local food products due to food safety concerns following the COVID-19 outbreak [7]. An online survey of 240 UK consumers looking at the effect of lockdown on their food attitudes, reported that after lockdown they placed more importance on health, mood, and weight control when choosing food, and less importance on familiarity [10]. In terms of purchase behaviour, an online survey of 362 Spanish consumers, reported that COVID-19 influenced their perceived purchase frequency of products across a wide range of product categories [3]. For example, they reported a decreased purchase frequency of short shelf life products such as fish and seafood, an increased purchase frequency of long shelf life products like pasta, and an increased purchase frequency of healthy products like vegetables and fruit. Perceived purchase frequency of meat also increased.

It is, however, important to note that the studies reported on above collected data from consumers at, or near, the height of the pandemic, and therefore, may not give an indication of consumer response to COVID-19 in the long term. When our study was conducted in November 2020, China had relatively low daily cases of COVID-19, city wide lockdowns had not been in place for many months, and the lifestyles of consumers had returned to a closer resemblance of normality in Shanghai and Beijing. The Chinese economy had also 
made a strong recovery by November 2020 [26]. Although the COVID-19 pandemic is still ongoing and many of the long-term consequences on consumers are still unknown, it is possible that with sufficient time many consumer habits with respect to food will return to normal [27].

\subsection{Consumer Clusters, Limitations of This Study and Practical Implications of This Research}

Cluster analysis revealed that 360/500 consumers (72\%) in December 2018 and 152/523 consumers (29\%) in November 2020 used a broad scale range and showed differential responses in importance ratings across numerous lamb attributes. However, the remaining clusters of consumers in December 2018 and November 2020 fell into a pattern of using a narrow scale range, effectively rating all lamb attributes at the point of purchase as important. While Asian consumers using a small scale range and higher on average scores in comparison to Western consumers is a common occurrence in sensory and consumer science [28-30], the large proportion of consumers who used such a narrow scale range was unexpected given that Likert scales have been used successfully in numerous studies in the past with Asian consumers [31,32]. The issue could be mitigated in future studies through the use of different types of survey methodologies, such as ranking based questions.

Results from this study, in particular comparisons with December 2018 and November 2020 consumers, are of course limited by the differences in demographic variables between the December 2018 and November 2020 consumers. Due to practical difficulties recruiting the same participants from the December 2018 survey, different consumers were recruited in November 2020. While recruitment ensured age and gender breakdowns were identical between years, other demographic characteristics (such as education, income, or other factors not measured) were not controlled for. A change in market research company used to recruit participants in December 2018 and November 2020 (which was also required for practical reasons), may have also contributed to small demographic differences between December 2018 and November 2020.

Finally, the results of this study provide assurance for producers and processors of lamb who export their products to China (especially those from New Zealand), that Chinese consumer preferences for lamb have not changed markedly since the outbreak of COVID-19. Exporters should feel confident that consumers in China who have valued the attributes of their lamb products in the past should continue to do so.

\section{Conclusions}

Between December 2018 and November 2020 (approximately nine months after the initial outbreak of COVID-19 in China) there was an increase in the proportion of Chinese consumers who buy their red meat online or at the butcher, and who cook their lamb to welldone, presumably as an implicit move towards safer food related behaviors. Interestingly, the importance consumers placed on a range of lamb attributes at the point of purchase and opinions towards New Zealand lamb did not vary over this time period.

Cluster analysis revealed that 140/500 consumers in December 2018 and 371/523 consumers in November 2020 used only a small scale range and thus assigned similar importance ratings to most lamb attributes raising some concerns about the suitability of the use of Likert scales for consumer research with Chinese consumers. Consequently, future research investigating the influence of COVID-19 or other food related topics on Chinese consumer attitudes should consider alternative survey methodologies to complement conventional scales to obtain greater discrimination across participants.

Author Contributions: Conceptualization, S.C.H., L.G., M.M., P.B., L.D. and C.E.R.; methodology, L.G. and C.E.R.; formal analysis, L.G., D.M. and E.P.; investigation, S.C.H. and C.E.R.; resources, M.M., L.D. and C.E.R.; data curation, S.C.H. and E.P.; writing-original draft preparation, S.C.H.; writingreview and editing, L.G., M.M., P.B., D.M., E.P., T.M.H., L.D. and C.E.R.; project administration, M.M. and C.E.R.; funding acquisition, M.M., L.D., P.B., and C.E.R. All authors have read and agreed to the published version of the manuscript. 
Funding: This research was funded by the New Zealand China Food Protection Network (Project RM 19169_3000037171) and the AgResearch Strategic Science Investment Fund, SSIF-A25692 (Consumer Experience: Delivering Customized Food Attributes).

Institutional Review Board Statement: Ethical approval was granted for this study by the University of Otago Human Ethics Committee (Category B), application number D20/355.

Informed Consent Statement: Informed consent was obtained from all subjects involved in the study.

Data Availability Statement: The data presented in this study are available on request from the corresponding author. Although consumer data have been anonymised, data are not publicly available.

Conflicts of Interest: The authors declare no conflict of interest.

\section{Appendix A}

ID Number:

Consumer Lamb Study

Demographic Questionnaire

\section{Gender}

$$
\square \text { Male } \quad \square \text { Female }
$$

2. Age

$\square$ 18-25

$\square$ 26-35

$\square 36-45$

$\square$ 46-60

$\square 61$ and over

3. Please provide the postcode for where you currently live:

4. Please provide the location of where you grew up (e.g. rural location or name of suburb, town or city):

5. What is your highest level of education?

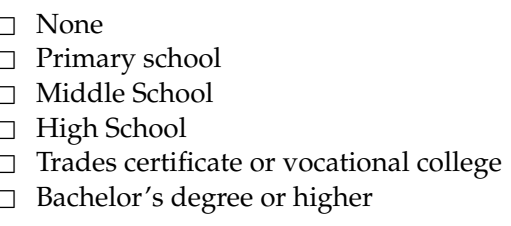

6. What is your occupation?
$\square$ Trades
$\square$ Professional
$\square$ Administration/Office
$\square$ Sales/Services
$\square$ Technical
$\square$ Labourer

7. Which of these income levels best represents your combine household income (or personal if single) per annum?

$$
\begin{aligned}
& \square \text { Less than } 50,000 \mathrm{CNY} \\
& \square 50,001 \text { to } 100,000 \mathrm{CNY} \\
& \square 100,001 \text { to } 150,000 \mathrm{CNY} \\
& \square 150,001 \text { to } 200,000 \mathrm{CNY} \\
& \square 200,001 \text { to } 300,000 \mathrm{CNY} \\
& \square 300,001 \text { to } 500,000 \mathrm{CNY} \\
& \square \text { More than } 500,000 \mathrm{CNY}
\end{aligned}
$$

8. How many people live in your household (adults are aged 18 and over).

$\begin{array}{lllllllll} & 1 & 2 & 3 & 4 & 5 & 6 & 7 & 8 \text { (or more) } \\ \text { Adults } & \square & \square & \square & \square & \square & \square & \square & \square \\ \text { Children } & \square & \square & \square & \square & \square & \square & \square & \square\end{array}$


9. Please indicate if you follow any of these diets (you may select more than one option).

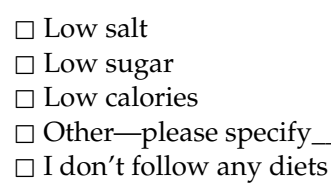

10. How often do you consume the following types of meat?

$\begin{array}{cccccccc}\text { Meat Type } & \text { Daily } & 4-5 \text { times a week } & \text { 2-3 times a week } & \text { Weekly } & \text { Fortnightly } & \text { Monthly } & \text { Never } \\ \text { Lamb } & \square & \square & \square & \square & \square & \square & \square \\ \text { Beef } & \square & \square & \square & \square & \square & \square & \square \\ \text { Pork } & \square & \square & \square & \square & \square & \square & \square \\ \text { Poultry } & \square & \square & \square & \square & \square & \square & \square \\ \text { Fish } & \square & \square & \square & \square & \square & \square & \square\end{array}$

11. When consuming grilled lamb, what level of cooking do you prefer?

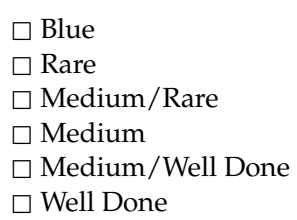

12. Where do you usually purchase red meat for your household?

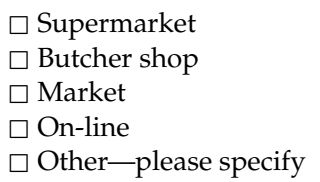

13. What qualities do you look for when purchasing red meat? (Select all applicable)

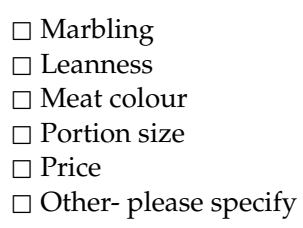

14. What lamb products do you typically purchase? (Select all applicable)

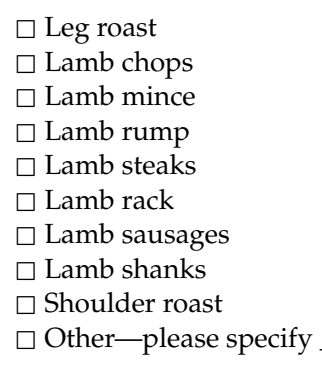

15. Please circle a number that indicates the level of importance each aspect is to you when purchasing lamb.

1. Animal origin

\begin{tabular}{ccccccccc}
\hline 1 & 2 & 3 & 4 & 5 & 6 & 7 & 8 & 9 \\
\hline $\begin{array}{c}\text { Not } \\
\text { Important }\end{array}$ & & & & & & & & $\begin{array}{c}\text { Very } \\
\text { Important }\end{array}$ \\
\hline
\end{tabular}

2. Animal welfare

\begin{tabular}{cllllllll}
\hline 1 & 2 & 3 & 4 & 5 & 6 & 7 & 8 & 9 \\
\hline $\begin{array}{c}\text { Not } \\
\text { Important }\end{array}$ & & & & & & Very \\
Important \\
\hline
\end{tabular}


3. Animal feeding

\begin{tabular}{ccccccccc}
\hline 1 & 2 & 3 & 4 & 5 & 6 & 7 & 8 & 9 \\
\hline $\begin{array}{c}\text { Not } \\
\text { Important }\end{array}$ & & & & & & & & $\begin{array}{c}\text { Very } \\
\text { Important }\end{array}$ \\
\hline
\end{tabular}

4. Animal age

\begin{tabular}{ccccccccc}
\hline 1 & 2 & 3 & 4 & 5 & 6 & 7 & 8 & 9 \\
\hline $\begin{array}{c}\text { Not } \\
\text { Important }\end{array}$ & & & & & & & & $\begin{array}{c}\text { Very } \\
\text { Important }\end{array}$ \\
\hline
\end{tabular}

5. Animal sex

\begin{tabular}{|c|c|c|c|c|c|c|c|c|}
\hline 1 & 2 & 3 & 4 & 5 & 6 & 7 & 8 & 9 \\
\hline $\begin{array}{c}\text { Not } \\
\text { Important }\end{array}$ & & & & & & & & $\begin{array}{c}\text { Very } \\
\text { Important }\end{array}$ \\
\hline
\end{tabular}

6. Presence of hormones and other residues

\begin{tabular}{ccccccccc}
\hline 1 & 2 & 3 & 4 & 5 & 6 & 7 & 8 & 9 \\
\hline $\begin{array}{c}\text { Not } \\
\text { Important }\end{array}$ & & & & & & & & $\begin{array}{c}\text { Very } \\
\text { Important }\end{array}$ \\
\hline
\end{tabular}

7. Traceability (to know history of meat you purchase)

\begin{tabular}{ccccccccc}
\hline 1 & 2 & 3 & 4 & 5 & 6 & 7 & 8 & 9 \\
\hline $\begin{array}{c}\text { Not } \\
\text { Important }\end{array}$ & & & & & & & & $\begin{array}{c}\text { Very } \\
\text { Important }\end{array}$ \\
\hline
\end{tabular}

8. Lamb price

\begin{tabular}{ccccccccc}
\hline 1 & 2 & 3 & 4 & 5 & 6 & 7 & 8 & 9 \\
\hline $\begin{array}{c}\text { Not } \\
\text { Important }\end{array}$ & & & & & & & & $\begin{array}{c}\text { Very } \\
\text { Important }\end{array}$ \\
\hline
\end{tabular}

9. Price of other meats

\begin{tabular}{ccccccccc}
\hline 1 & 2 & 3 & 4 & 5 & 6 & 7 & 8 & 9 \\
\hline $\begin{array}{c}\text { Not } \\
\text { Important }\end{array}$ & & & & & & & & $\begin{array}{c}\text { Very } \\
\text { Important }\end{array}$ \\
\hline $\begin{array}{c}\text { 10. } \\
\text { Fat content of meat }\end{array}$ & 2 & 3 & 4 & 5 & 6 & 7 & 8 & 9 \\
\hline 1 & & & & & & & & $\begin{array}{c}\text { Very } \\
\text { Important }\end{array}$ \\
\hline $\begin{array}{c}\text { Not } \\
\text { Important }\end{array}$ & & & & & & & & \\
\hline
\end{tabular}

11. General meat appearance (shiny, dry...etc.)

\begin{tabular}{ccccccccc}
\hline 1 & 2 & 3 & 4 & 5 & 6 & 7 & 8 & 9 \\
\hline $\begin{array}{c}\text { Not } \\
\text { Important }\end{array}$ & & & & & & & & $\begin{array}{c}\text { Very } \\
\text { Important }\end{array}$ \\
\hline
\end{tabular}

12. Meat colour

\begin{tabular}{ccccccccc}
\hline 1 & 2 & 3 & 4 & 5 & 6 & 7 & 8 & 9 \\
\hline $\begin{array}{c}\text { Not } \\
\text { Important }\end{array}$ & & & & & & & & $\begin{array}{c}\text { Very } \\
\text { Important }\end{array}$ \\
\hline
\end{tabular}


13. Meat flavour

\begin{tabular}{ccccccccc}
\hline 1 & 2 & 3 & 4 & 5 & 6 & 7 & 8 & 9 \\
\hline $\begin{array}{c}\text { Not } \\
\text { Important }\end{array}$ & & & & & & & & $\begin{array}{c}\text { Very } \\
\text { Important }\end{array}$ \\
\hline
\end{tabular}

14. Meat texture (tenderness)

\begin{tabular}{ccccccccc}
\hline 1 & 2 & 3 & 4 & 5 & 6 & 7 & 8 & 9 \\
\hline $\begin{array}{c}\text { Not } \\
\text { Important }\end{array}$ & & & & & & & & $\begin{array}{c}\text { Very } \\
\text { Important }\end{array}$ \\
\hline
\end{tabular}

15. Risk of catching a disease consuming lamb (food safety)

\begin{tabular}{|c|c|c|c|c|c|c|c|c|}
\hline 1 & 2 & 3 & 4 & 5 & 6 & 7 & 8 & 9 \\
\hline $\begin{array}{c}\text { Not } \\
\text { Important }\end{array}$ & & & & & & & & $\begin{array}{c}\text { Very } \\
\text { Important }\end{array}$ \\
\hline
\end{tabular}

16. Place of purchase

\begin{tabular}{ccccccccc}
\hline 1 & 2 & 3 & 4 & 5 & 6 & 7 & 8 & 9 \\
\hline $\begin{array}{c}\text { Not } \\
\text { Important }\end{array}$ & & & & & & & & $\begin{array}{c}\text { Very } \\
\text { Important }\end{array}$ \\
\hline
\end{tabular}

17. Trust in butcher

\begin{tabular}{ccccccccc}
\hline 1 & 2 & 3 & 4 & 5 & 6 & 7 & 8 & 9 \\
\hline $\begin{array}{c}\text { Not } \\
\text { Important }\end{array}$ & & & & & & & & $\begin{array}{c}\text { Very } \\
\text { Important }\end{array}$ \\
\hline
\end{tabular}

18. Time of the day in which you can purchase lamb

\begin{tabular}{ccccccccc}
\hline 1 & 2 & 3 & 4 & 5 & 6 & 7 & 8 & 9 \\
\hline $\begin{array}{c}\text { Not } \\
\text { Important }\end{array}$ & & & & & & & & $\begin{array}{c}\text { Very } \\
\text { Important }\end{array}$ \\
\hline
\end{tabular}

19. Brand or quality label

\begin{tabular}{ccccccccc}
\hline 1 & 2 & 3 & 4 & 5 & 6 & 7 & 8 & 9 \\
\hline $\begin{array}{c}\text { Not } \\
\text { Important }\end{array}$ & & & & & & & & $\begin{array}{c}\text { Very } \\
\text { Important }\end{array}$ \\
\hline 20. Label information & & & & & & & \\
\hline 1 & 2 & 3 & 4 & 5 & 6 & 7 & 8 & 9 \\
\hline $\begin{array}{c}\text { Not } \\
\text { Important }\end{array}$ & & & & & & & $\begin{array}{c}\text { Very } \\
\text { Important }\end{array}$ \\
\hline
\end{tabular}

21. Presentation (pieces, slices, trays...etc)

\begin{tabular}{ccccccccc}
\hline 1 & 2 & 3 & 4 & 5 & 6 & 7 & 8 & 9 \\
\hline $\begin{array}{c}\text { Not } \\
\text { Important }\end{array}$ & & & & & & & & $\begin{array}{c}\text { Very } \\
\text { Important }\end{array}$ \\
\hline
\end{tabular}

22. Easy to prepare/cook

\begin{tabular}{ccccccccc}
\hline 1 & 2 & 3 & 4 & 5 & 6 & 7 & 8 & 9 \\
\hline $\begin{array}{c}\text { Not } \\
\text { Important }\end{array}$ & & & & & & & & $\begin{array}{c}\text { Very } \\
\text { Important }\end{array}$ \\
\hline
\end{tabular}


23. Dish to be prepared with it

\begin{tabular}{ccccccccc}
\hline 1 & 2 & 3 & 4 & 5 & 6 & 7 & 8 & 9 \\
\hline $\begin{array}{c}\text { Not } \\
\text { Important }\end{array}$ & & & & & & & & $\begin{array}{c}\text { Very } \\
\text { Important }\end{array}$ \\
\hline
\end{tabular}

24. My knowledge of different commercial cuts

\begin{tabular}{ccccccccc}
\hline 1 & 2 & 3 & 4 & 5 & 6 & 7 & 8 & 9 \\
\hline $\begin{array}{c}\text { Not } \\
\text { Important }\end{array}$ & & & & & & & & $\begin{array}{c}\text { Very } \\
\text { Important }\end{array}$ \\
\hline
\end{tabular}

25. Value for money

\begin{tabular}{|c|c|c|c|c|c|c|c|c|}
\hline 1 & 2 & 3 & 4 & 5 & 6 & 7 & 8 & 9 \\
\hline $\begin{array}{c}\text { Not } \\
\text { Important }\end{array}$ & & & & & & & & $\begin{array}{c}\text { Very } \\
\text { Important }\end{array}$ \\
\hline
\end{tabular}

26. Others (indicate)

\begin{tabular}{ccccccccc}
\hline 1 & 2 & 3 & 4 & 5 & 6 & 7 & 8 & 9 \\
\hline $\begin{array}{c}\text { Not } \\
\text { Important }\end{array}$ & & & & & & & & $\begin{array}{c}\text { Very } \\
\text { Important }\end{array}$ \\
\hline
\end{tabular}

16. In your opinion New Zealand lamb ......

\begin{tabular}{|c|c|c|c|c|c|c|c|}
\hline & 1 & 2 & 3 & 4 & 5 & 6 & 7 \\
\hline & $\begin{array}{l}\text { Strongly } \\
\text { disagree }\end{array}$ & & & $\begin{array}{l}\text { Neither } \\
\text { disagree } \\
\text { nor agree }\end{array}$ & & & $\begin{array}{c}\text { Strongly } \\
\text { Agree }\end{array}$ \\
\hline Is nutritious & $\square$ & $\square$ & $\square$ & $\square$ & $\square$ & $\square$ & $\square$ \\
\hline Is healthy & $\square$ & $\square$ & $\square$ & $\square$ & $\square$ & $\square$ & $\square$ \\
\hline Is well known & $\square$ & $\square$ & $\square$ & $\square$ & $\square$ & $\square$ & $\square$ \\
\hline Is unique & $\square$ & $\square$ & $\square$ & $\square$ & $\square$ & $\square$ & $\square$ \\
\hline Is safe & $\square$ & $\square$ & $\square$ & $\square$ & $\square$ & $\square$ & $\square$ \\
\hline $\begin{array}{l}\text { Is good value for } \\
\text { money }\end{array}$ & $\square$ & $\square$ & $\square$ & $\square$ & $\square$ & $\square$ & $\square$ \\
\hline Is boring & $\square$ & $\square$ & $\square$ & $\square$ & $\square$ & $\square$ & $\square$ \\
\hline Is a traditional product & $\square$ & $\square$ & $\square$ & $\square$ & $\square$ & $\square$ & $\square$ \\
\hline Is natural & $\square$ & $\square$ & $\square$ & $\square$ & $\square$ & $\square$ & $\square$ \\
\hline Is hard to digest & $\square$ & $\square$ & $\square$ & $\square$ & $\square$ & $\square$ & $\square$ \\
\hline $\begin{array}{l}\text { Is produced } \\
\text { sustainably }\end{array}$ & $\square$ & $\square$ & $\square$ & $\square$ & $\square$ & $\square$ & $\square$ \\
\hline Is convenient & $\square$ & $\square$ & $\square$ & $\square$ & $\square$ & $\square$ & $\square$ \\
\hline Is readily available & $\square$ & $\square$ & $\square$ & $\square$ & $\square$ & $\square$ & $\square$ \\
\hline Is high quality & $\square$ & $\square$ & $\square$ & $\square$ & $\square$ & $\square$ & $\square$ \\
\hline Contains no additive & $\square$ & $\square$ & $\square$ & $\square$ & $\square$ & $\square$ & $\square$ \\
\hline Makes people feel good & $\square$ & $\square$ & $\square$ & $\square$ & $\square$ & $\square$ & $\square$ \\
\hline Tastes good & $\square$ & $\square$ & $\square$ & $\square$ & $\square$ & $\square$ & $\square$ \\
\hline
\end{tabular}




\section{References}

1. Parma, V.; Ohla, K.; Veldhuizen, M.G.; Niv, M.Y.; Kelly, C.E.; Bakke, A.J.; Cooper, K.W.; Bouysset, C.; Pirastu, N.; Dibattista, M.; et al. More Than Smell-COVID-19 is associated with severe impairment of smell, taste, and chemesthesis. Chem. Senses 2020, 45, 609-622. [CrossRef]

2. Klein, H.; Asseo, K.; Karni, N.; Benjamini, Y.; Nir-Paz, R.; Muszkat, M.; Israel, S.; Niv, M.Y. Onset, duration, and persistence of taste and smell changes and other COVID-19 symptoms: Longitudinal study in Israeli patients. medRxiv 2020. [CrossRef]

3. Laguna, L.; Fiszman, S.; Puerta, P.; Chaya, C.; Tárrega, A. The impact of COVID-19 lockdown on food priorities. Results from a preliminary study using social media and an online survey with Spanish consumers. Food Qual. Prefer. 2020, 86, 104028. [CrossRef]

4. Li, J.; Hallsworth, A.G.; Coca-Stefaniak, J.A. Changing grocery shopping behaviours among chinese consumers at the outset Of The COVID-19 outbreak. Tijdschr. Econ. Soc. Geogr. 2020, 111, 574-583. [CrossRef] [PubMed]

5. Mehta, S.; Saxena, T.; Purohit, N. The new consumer behaviour paradigm amid COVID-19: Permanent or transient? J. Health Manag. 2020, 22, 291-301. [CrossRef]

6. Zwanka, R.J.; Buff, C. COVID-19 Generation: A conceptual framework of the consumer behavioral shifts to be caused by the COVID-19 Pandemic. J. Int. Consum. Mark. 2021, 33, 58-67. [CrossRef]

7. Ben Hassen, T.; El Bilali, H.; Allahyari, M.S. Impact of COVID-19 on food behavior and consumption in Qatar. Sustainability 2020, 12, 6973. [CrossRef]

8. Gao, X.; Shi, X.; Guo, H.; Liu, Y. To buy or not buy food online: The impact of the COVID-19 epidemic on the adoption of e-commerce in China. PLoS ONE 2020, 15, e0237900. [CrossRef] [PubMed]

9. Chang, H.-H.; Meyerhoefer, C.D. COVID-19 and the demand for online food shopping services: Empirical evidence from Taiwan. Am. J. Agric. Econ. 2021, 103, 448-465. [CrossRef]

10. Snuggs, S.; McGregor, S. Food \& meal decision making in lockdown: How and who has Covid-19 affected? Food Qual. Prefer. 2021, 89, 104145. [CrossRef]

11. Bernués, A.; Olaizola, A.; Corcoran, K. Extrinsic attributes of red meat as indicators of quality in Europe: An application for market segmentation. Food Qual. Prefer. 2003, 14, 265-276. [CrossRef]

12. Attwood, S.; Hajat, C. How will the COVID-19 pandemic shape the future of meat consumption? Public Health Nutr. 2020, 23, 3116-3120. [CrossRef]

13. Clemens, R.L.; Babcock, B.A. Country of origin as a brand: The case of New Zealand lamb. MATRIC Brief. Pap. 2004, 5, 1-25.

14. Sofos, J. Microbial growth and its control in meat, poultry and fish. In Quality Attributes and Their Measurement in Meat, Poultry and Fish Products; Springer: Berlin/Heidelberg, Germany, 1994; pp. 359-403.

15. Beef and Lamb New Zealand. Available online: https://beeflambnz.com/sites/default/files/New\%20Season\%20Outlook\%Nov202019-20\%20-\%20Report.pdf (accessed on 20 April 2021).

16. Meat and Livestock Australia. Available online: https://www.mla.com.au/prices-markets/market-news/Nov-2020/newzealands-red-meat-industry-remains-robust-despite-challenges/\# (accessed on 20 April 2021).

17. Food and Agriculture Organization of the United Nations. Countries by Commodity. Available online: http://www.fao.org/ faostat/en/\#rankings/countries_by_commodity_imports (accessed on 20 April 2021).

18. Aschemann-Witzel, J.; Peschel, A.O. How circular will you eat? The sustainability challenge in food and consumer reaction to either waste-to-value or yet underused novel ingredients in food. Food Qual. Prefer. 2019, 77, 15-20. [CrossRef]

19. Tan, H.S.G.; Verbaan, Y.T.; Stieger, M. How will better products improve the sensory-liking and willingness to buy insect-based foods? Food Res. Int. 2017, 92, 95-105. [CrossRef] [PubMed]

20. Zhou, G.; Zhang, W.; Xu, X. China's meat industry revolution: Challenges and opportunities for the future. Meat Sci. 2012, 92, 188-196. [CrossRef] [PubMed]

21. Meixner, O.; Katt, F. Assessing the impact of COVID-19 on consumer food safety perceptions-A choice-based willingness to pay study. Sustainability 2020, 12, 7270. [CrossRef]

22. Xie, X.; Huang, L.; Li, J.; Zhu, H. Generational differences in perceptions of food health/risk and attitudes toward organic food and game meat: The case of the COVID-19 crisis in China. Int. J. Environ. Res. Public Health 2020, 17, 3148. [CrossRef] [PubMed]

23. Kim, H.-J.; Lee, M.-J.; Lee, S.-K.; Kim, D.-Y.; Seo, S.-J.; Kang, H.-E.; Nam, H.-M. African swine fever virus in pork brought into South Korea by travelers from China, August 2018. Emerg. Infect. Dis. 2019, 25, 1231. [CrossRef] [PubMed]

24. Gale, F.; Hu, D.; Marti, D. China's Volatile Pork Industry; United States Department of Agriculture: Washington, DC, USA, 2012.

25. Qin, A. Coronavirus Fears in China Find a New Target: Salmon. Available online: https://www.nytimes.com/Nov-2020/06/18 /world/asia/coronavirus-china-salmon.html (accessed on 30 April 2021).

26. National Bureau of Statistics of China. Preliminary Accounting Results of GDP for the Fourth Quarter and the Whole Year of 2020. Available online: http:/ / www.stats.gov.cn/english/PressRelease/202101/t20210120_1812680.html (accessed on 20 April 2021).

27. Sheth, J. Impact of Covid-19 on consume behavior: Will the old habits return or die? J. Bus. Res. 2020, 117, 280-283. [CrossRef]

28. Yeh, L.L.; Kim, K.O.; Chompreeda, P.; Rimkeeree, H.; Yau, N.J.N.; Lundahl, D.S. Comparison in Use of the 9-Point Hedonic Scale between Americans, Chinese, Koreans, and Thai. Food Qual. Prefer. 1998, 9, 413-419. [CrossRef]

29. Johnson, T.P.; Shavitt, S.; Holbrook, A.L. Survey response styles across cultures. In Cross-Cultural Research Methods in Psychology; Cambridge University Press: New York, NY, USA, 2011; pp. 130-175. 
30. Ares, G.; Giménez, A.; Vidal, L.; Zhou, Y.; Krystallis, A.; Tsalis, G.; Symoneaux, R.; Cunha, L.M.; de Moura, A.P.; Claret, A.; et al. Do we all perceive food-related wellbeing in the same way? Results from an exploratory cross-cultural study. Food Qual. Prefer. 2016, 52, 62-73. [CrossRef]

31. Sternquist, B.; Byun, S.-E.; Jin, B. The dimensionality of price perceptions: A cross-cultural comparison of Asian consumers. Int. Rev. Retail. Distrib. Consum. Res. 2004, 14, 83-100. [CrossRef]

32. Liu, A.; Niyongira, R. Chinese consumers food purchasing behaviors and awareness of food safety. Food Control 2017, 79, 185-191. [CrossRef] 